\title{
Pawet Przytęcki
}

(Uniwersytet Medyczny w Łodzi, Zakład Socjologii)

\section{Społeczno-polityczne i religijne aspekty „in vitro" w Polsce}

\section{Wstęp}

W prowadzonym w Polsce po 1989 r. dyskursie, kwestie społeczne co pewien czas pojawiaja się - aby potem zamilknaćc na moment - tematy o charakterze medycznym, które są nie tylko ważne społecznie, ale przede wszystkim kontrowersyjne, bowiem wywołuja sprzeczności o charakterze etycznym, religijnym oraz politycznym. Nie sa to jednak jakiekolwiek problemy społeczne, ale te dotyczace życia ludzkiego. Jednym z nich jest aborcja, która jednak została prawnie uregulowana i możemy obecnie mówić o pewnym status quo, choć zarówno ugrupowania prawicowe, jak i lewicowe, chciałyby dokonać zmian w tym zakresie. Drugim takim problemem jest kwestia możliwości i zakresu stosowania metody sztucznego zapłodnienia in vitro. Trzecim problemem, obecnie sporadycznie wywoływanym w debacie społecznej, głównie ze względu na brak silnych środowisk politycznych chcacych wprowadzić to zagadnienie w obręb prowadzonego dyskursu polityki, jest eutanazja. Można jednak antycypować, iż jest to tylko kwestia przyszłości.

Polska jest jednym z nielicznych państw w Europie, które nie maja prawnie uregulowanej kwestii wykonywania zabiegów sztucznego zapłodnienia. W tym przypadku dotyczy to głównie zapłodnienia pozaustrojowego in vitro, które $\mathrm{w}$ przeciwieństwie do zapłodnienia in vivo jest o wiele bardziej skomplikowane, wielokrotnie droższe i przyglądajacc się prowadzonej w Polsce debacie, w większym stopniu antagonizujące różne środowiska. Dlatego też w dalszej części artykułu będę odnosił się przede wszystkim do zapłodnienia in vitro. Krajowy ustawodawca dotychczas nie uregulował prawnie kwestii tej formy zapłodnienia, przez co w rzeczywistości w Polsce sa wykonywane zabiegi in vitro przez prywatne kliniki, jednak ich działalność nie odbywa się na bazie jasno określonych zasad. Dlatego też kliniki te nie są nawet zobowiązane do przekazywania 
dokładnych danych, na przykład w zakresie liczby wykonywanych zabiegów i ich skuteczności. Brak przepisów nadrzędnych w tym zakresie może w rzeczywistości działać na niekorzyść samych pacjentów. Tym samym to często specjalista podejmuje istotne decyzje dotyczace na przykład liczby tworzonych embrionów, a następnie ich ewentualnego zniszczenia lub zamrożenia. Pacjenci, często nieposiadajacy specjalistycznej wiedzy w tym zakresie, przyjmuja jako wyznacznik opinię lekarza.

Celem tego artykułu jest przyjrzenie się prowadzonej w Polsce dyskusji na temat sztucznego zapłodnienia, zarówno przez środowiska polityczne, jak i religijne, naukowe oraz społeczne, a następnie dokonanie próby wyjaśnienia obecnego status quo w tym zakresie. Pomimo iż pierwsze udane zapłodnienie in vitro, zakończone urodzeniem zdrowej osoby na świecie miało miejsce w Anglii w 1978 r., a w Polsce było to w 1987 r., to sztuczne zapłodnienie wciąż jest tematem, który antagonizuje różne grupy społeczne. Obecnie, dokonując analizy prowadzonego dyskursu w Polsce, można zauważyć istotne rozbieżności dotyczące tej techniki zapłodnienia. Poszczególne środowiska społeczno-religijne i polityczne wyrażaja sprzeczne stanowiska w zakresie tego:

a) czy niepłodność jest chorobą i w związku z tym, czy powinna być leczona;

b) czy sztuczne zapłodnienie jest metodą leczenia niepłodności, czy jedynie techniczna manipulacja, która w rzeczywistości i tak nie usuwa przyczyny braku zapłodnienia;

c) czy posiadanie dziecka z probówki nie jest jedynie kwestią egoizmu rodziców;

d) jaki jest status prawny i moralny zarodka;

e) czy embrion powinien mieć zagwarantowane takie samo prawo do życia jak dziecko narodzone.

\section{Sztuczne zapłodnienie - zagadnienia terminologiczne}

Sztuczne zapłodnienie polega na połączeniu komórki jajowej z plemnikiem przy pomocy osoby trzeciej, jaka jest specjalizujący się w tym lekarz. Należy jednak zwrócić uwagę na to, że w rzeczywistości sztuczne zapłodnienie, pomimo iż pod względem technicznym jest przeprowadzane w podobny sposób, to jednak biorac pod uwage możliwe konfiguracje osób, które przekazują materiał genetyczny, wyróżnia się różne określenia dotyczące sztucznego zapłodnienia. W rzeczywistości mają one znaczenie prawne, ale i etyczne. Należy podkreślić, iż sztuczne zapłodnienie może mieć charakter zapłodnienia wewnątrzustrojowego (in vivo; nazywane również inseminacją), gdy pobrane nasienie jest wstrzykiwane 
przez specjaliste do ciała kobiety oraz zapłodnienie pozaustrojowe (in vitro), gdy do połączenia plemnika z komórka jajową dochodzi „w szkle”, czyli w wyspecjalizowanym laboratorium, a następnie wyhodowany embrion przenoszony jest do ciała kobiety. Jednocześnie sztuczne zapłodnienie może mieć charakter homologiczny (gdy dawcami gamet są małżonkowie) oraz heterologiczny (gdy jednym z dawców gamety jest osoba trzecia, może to być zarówno inny mężczyzna jako dawca nasienia oraz inna kobieta jako dawca komórki jajowej. Zapłodnienie homologiczne i heterologiczne dotyczy zarówno zapłodnienia in vivo, jak i in vitro. Można jeszcze wskazać na zapłodnienie mieszane, gdy ze względu na złe parametry nasienia mężczyzny do zapłodnienia komórki jajowej stosowana jest mieszanina nasienia męża i innego dawcy (Szewczyk 2009: 187-188).

Powyższe rozróżnienie ma istotne znaczenie, w kontekście prowadzonego dyskursu przez różne środowiska, w tym dla polityków, deliberujących na temat prawnego usankcjonowania poszczególnych form sztucznego zapłodnienia, głównie in vitro. Kwestia sporną nie jest bowiem jedynie to, czy zapłodnienie in vitro powinno być dozwolone, a jednocześnie finansowane ze środków publicznych, ale również to, czy wszystkie rodzaje sztucznego zapłodnienia powinny być traktowane na równi? Jednocześnie należy zaznaczyć, iż rozróżnienia terminologiczne dotyczące sztucznego zapłodnienia nie mają w rzeczywistości większej różnicy dla katolickich teologów, według których zarówno zapłodnienie in vivo, jak i in vitro, homologiczne $\mathrm{i}$ heterologiczne, jest uważane za moralnie złe i niedopuszczalne.

\section{Religijne aspekty in vitro}

Dyskusja nad in vitro w Polsce i za granica prowadzona jest od wielu lat. Pomimo że społeczne przyzwolenie na wykorzystywanie tej metody w przypadku osób borykających się z niepłodnością, zarówno żeńską, jak i męska jest znaczące, to jednak nie można zapomnieć o tym, że występują również oponenci tej techniki. Argumenty podawane przez przeciwników wykorzystywania metody in vitro do leczenia niepłodności sa głównie natury moralno-religijnej. W rzeczywistości jednak można by również zastanowić się nad tym, czy w przypadku niektórych środowisk, głównie politycznych, ma miejsce jeszcze inny kontrargument za usankcjonowaniem metody in vitro - czyli polityczny i finansowy. Za najistotniejsze uchodza jednak argumenty głoszone przez katolickich teologów, którzy stanowczo neguja możliwość stosowania sztucznego zapłodnienia, uznając je za grzech ciężki.

Problem sztucznego zapłodnienia nie jest jednak jednoznacznie uważany za niegodny człowieka i tym samym niemożliwy do zaakceptowania 
nie tylko przez poszczególne religie, ale także wyznania chrześcijańskie. W dyskursie prowadzonym w Polsce na temat in vitro dominujace znaczenie ma nauka katolicka, której zręby w tym zakresie zostaną poniżej przedstawione. Jednakże dla celów porównawczych przedstawione zostaną również główne założenia wybranych wyznań chrześcijańskich - prawosławia i luteranizmu oraz religii, takich jak judaizm i islam.

Podstawy nauczania Kościoła katolickiego odnośnie do sztucznego zapłodnienia zawarte sa $\mathrm{w}$ dwóch dokumentach opracowanych przez Kongregacje Nauki Wiary: Donum vitae. Instrukcja o szacunku dla rodzacego się życia ludzkiego i o godności jego przekazywania z $1987 \mathrm{r}$. oraz Instrukcja Dignitas personae dotyczaca niektórych problemów bioetycznych z 2008 r.

Kościół katolicki sprzeciwia się jakiejkolwiek formie sztucznego zapłodnienia, zarówno in vivo, jak i in vitro, bowiem jedynym akceptowalnym sposobem poczęcia ludzkiego jest ,[...] stosunek płciowy mężczyzny z kobieta. [Ponadto - przyp. P. P.] rodzicielstwo prawdziwie odpowiedzialne w stosunku do majacego przyjść na świat dziecka winno być owocem małżeństwa" (Donum vitae 1987). Kolejnym argumentem przeciwko możliwości stosowania sztucznego zapłodnienia jest kwestia statusu ontologicznego zarodka. Zgodnie z nauką Kościoła katolickiego „od momentu, w którym jajo zostaje zapłodnione, rozpoczyna się nowe życie, które nie jest życiem ojca lub matki, lecz nowej istoty ludzkiej rozwijającej się niezależnie od nich" (Donum vitae 1987). Tym samym embrion, powstały po połączeniu komórki jajowej z plemnikiem, należy uznać za żywy organizm, człowieka, któremu należy się takie samo prawo do życia, jak osobom narodzonym. Nadanie człowieczeństwa embrionowi stanowi zatem jeden $\mathrm{z}$ najważniejszych argumentów przeciwko zapłodnieniu in vitro, bowiem ze względu na złożoność tej procedury, najczęściej dochodzi do zapłodnienia więcej niż jednego embrionu, co, jak tłumaczą specjaliści od sztucznego zapłodnienia, zwiększa prawdopodobieństwo zapłodnienia. Zarodek jest transportowany do organizmu kobiety dopiero po kilku dniach. Wcześniej poszczególne embriony rozwijaja się $\mathrm{w}$ warunkach sztucznych i specjalista podejmuje decyzję, który z nich ma największe szanse na przeżycie w ciele kobiety. Jest to kolejny istotny powód, dla którego Kościół katolicki nie może zaakceptować tej techniki radzenia sobie z niepłodnością. To zjawisko jest określane przez teologów katolickich jako „wyrafinowana aborcja” (Zagrodzki 2008: 79). Środowiska umiarkowane, propagujace sztuczne zapłodnienie metodą in vitro, a jednocześnie pragnące przynajmniej częściowo pogodzić tę formę zapłodnienia z nauką Kościoła katolickiego, proponują ograniczenie tworzenia embrionów do jednego lub dwóch, w przypadku gdyby oba były przenoszone do ciała kobiety. Jednakże, jak podkreśla teolog katolicki Wojciech Bołoz, nie jest w zasadzie możliwe wyeliminowanie zjawiska 
niszczenia zarodków, bowiem procedura in vitro „[...] powoduje zawsze jakieś aberracje chromosomalne i genetyczne, dlatego pewna część zarodków pozostanie $\mathrm{z}$ wadami i z tego powodu zostana zniszczone" (Zagrodzki 2008: 80). Kościół katolicki nie dopuszcza również możliwości zamrażania embrionów, gdyż stanowi to „(...) obrazę dla szacunku należnego istotom ludzkim, ponieważ wystawia je na wielkie niebezpieczeństwo śmierci lub naruszenia ich integralności fizycznej, pozbawia je, przynajmniej czasowo, rozwoju w łonie matki i pozostawia w sytuacji, w której sa narażone na dalsze szkody i manipulacje" (Donum vitae 1987).

Choć sztuczne zapłodnienie nie jest akceptowane przez większość dominujących na świecie religii, to jednak tylko katolicyzm wyraża pełny sprzeciw wobec jakiejkolwiek innej, niż droga naturalna, formy zapłodnienia. Poniżej zostana przedstawione, w celu porównawczym, stanowiska wybranych religii. W pierwszej kolejności warto przyjrzeć się poglądom głoszonym na ten temat przez inne niż katolicyzm wyznania chrześcijańskie.

W przypadku wyznania prawosławnego przedstawione zostanie oficjalne stanowisko Kościoła w Grecji i Rosji. Poglądy kościoła prawosławnego sa $\mathrm{w}$ wielu elementach zbieżne z tymi głoszonymi przez katolicyzm. Kościół prawosławny podkreśla wagę życia ludzkiego, „[...] które jest święte i nienaruszalne od samego poczatku. [Zarodek - przyp. P. P.] od chwili zaistnienia w momencie poczęcia posiada nie tylko swoją własną tożsamość genetyczną, ale operuje własną tożsamością osobową" (Aleksiejuk 2008: 54). Chrześcijanie prawosławni podkreślaja, iż nowe życie „[...] powinno dokonywać się [...] w poszanowaniu godności, szacunku i bojaźni Bożej" (Aleksiejuk 2008: 55). Kościół prawosławny, w przeciwieństwie do katolickiego, nie udziela jednak jednoznacznej odpowiedzi na pytanie, czy zapłodnienie pozaustrojowe jest działaniem wbrew woli Bożej (Aleksiejuk 2008: 55). W rzeczywistości wśród teologów prawosławnych istnieją podzielone stanowiska w zakresie stosowania sztucznego zapłodnienia. Kościół prawosławny nie rekomenduje stosowania tej techniki w przypadku występującej niepłodności, twierdząc, iż lepszym rozwiązaniem jest adopcja dzieci. Jednakże Rada ds. Etyki Biomedycznej przy Patriarchacie Moskiewskim stwierdziła w komunikacie wydanym w 2007 r., że możliwe byłoby dopuszczenie do zapłodnień in vitro w przypadku gdy: a) dotyczyłoby tylko małżeństw; b) zakazane byłoby tworzenie i niszczenie embrionów nadliczbowych; c) małżeństwa posiadałyby odpowiednie orzeczenie lekarskie stwierdzające, iż naturalny rozród nie jest możliwy (Aleksiejuk 2008: 60-61).

W przypadku wyznań protestanckich nie ma jednego wypracowanego podejścia do kwestii zapłodnienia pozaustrojowego. Nawet w przypadku jednego wyznania niekiedy zauważalne sa różnice, tak jak w przypad$\mathrm{ku}$ luteranizmu. Dlatego też przedstawione zostanie jedynie stanowisko 
największego w Polsce wyznania protestanckiego, tj. Kościoła Ewangelicko-Augsburskiego (luterańskiego) w Rzeczpospolitej Polskiej. Zgodnie z przyjęta w 2009 r. uchwała przez synod luterańskiego Kościoła Ewangelicko-Augsburskiego, stosowanie metody homologicznego sztucznego zapłodnienia zostało uznane za moralnie dopuszczalne, będące forma wspierania rodziny. Jednocześnie kościół luterański nie wyraża aprobaty dla sztucznego zapłodnienia heterologicznego, sprzeciwia się również niszczeniu ludzkiego embrionu czy wykorzystywaniu go do celów badawczych (oświadczenie Kościoła Ewangelicko-Augsburskiego w RP).

$\mathrm{Z}$ religii niechrześcijańskich przedstawione zostana dwa stanowiska - judaizmu oraz islamu. W judaizmie stwarzanie nowego życia jest uważane za wypełnienie biblijnego przykazania. Dlatego też, pomimo istniejących kontrowersji pomiędzy poszczególnymi rabinami, większość uważa, iż metoda in vitro powinna być dopuszczalna w przypadku problemów z niepłodnościa. W przypadku judaizmu akceptacja dla sztucznego zapłodnienia, jak i niszczenia embrionów jest o tyle możliwa, iż uważa się, że do czterdziestego dnia od zapłodnienia embrion nie jest jeszcze organizmem (Makosz 2008b: 93). Ponadto, według prawa żydowskiego, zarodkowi powstałemu w warunkach sztucznych, który jeszcze nie został przeniesiony do ciała kobiety, nie można nadać statusu potencjalnego życia, a tym samym zniszczenie go nie budzi określonych moralnych watpliwości (Makosz 2008a: 65-68). Większe rozbieżności pomiędzy poszczególnymi autorytetami religijnymi występuja w zakresie poszczególnych rodzajów stosowania in vitro. Tym samym rozbieżności sa zauważalne $\mathrm{w}$ takich kwestiach jak sztuczne zapłodnienie heterologiczne (Makosz 2008a: 65).

Islam w przypadku niepłodności małżonków dopuszcza wykorzystanie sztucznego zapłodnienia in vivo oraz in vitro, jednak tylko pod warunkiem, że dochodzi do zapłodnienia komórek rozrodczych męża i żony. Jednocześnie islam nie dopuszcza możliwości stosowania różnych form zapłodnienia heterologicznego, w tym przenoszenia embrionu zapłodnionego komórkami męża i żony do organizmu surogatki (Ali, bdw.).

\section{Prawne podstawy sztucznego zapłodnienia w Polsce}

Kluczowym dokumentem, stanowiącym podstawe w działaniach dotyczacych zapłodnienia in vitro jest Konwencja o ochronie praw człowieka $i$ godności istoty ludzkiej $w$ dziedzinie zastosowania biologii $i$ medycyny (dalej: Europejska Konwencja Bioetyczna), uchwalona w 1997 r. przez Radę Europy. Polska konwencję tę podpisała w 1999 r., jednak do tej pory nie została ona ratyfikowana przez Parlament. Konwencja ta jest pierwszym międzynarodowym dokumentem, który wskazał na powiązania 
pomiędzy biomedycyna a kwestia ochrony praw człowieka. Jest to dokument określający minimalny standard ochrony, zatem państwo będące sygnatariuszem Konwencji może, jeśli chce, zagwarantować ochronę silniejsza (Grzymkowska, bdw.: 1). Konwencja nie podejmuje kwestii trudnych, takich jak aborcja czy eutanazja. Odnosi się jednak do kwestii zapłodnienia in vitro, aczkolwiek w bardzo ogólny sposób, stwierdzając jedynie, iż w przypadku prowadzenia badań na embrionach in vitro, embrionom tym powinna być zagwarantowana odpowiednia ochrona. Jednocześnie należy podkreślić, iż w Konwencji nie zdefiniowano, czym jest embrion. Ponadto, zakazano tworzenia zarodków ludzkich dla celów naukowych (Konwencja, art. 18). Natomiast za możliwe uznano dokonywanie zmian w genomie ludzkim, jednak tylko w celach profilaktycznych, terapeutycznych i diagnostycznych, gdy celem takiej interwencji nie będzie wywołanie dziedzicznych zmian genetycznych $\mathrm{u}$ potomstwa (Konwencja, art. 13). Zakazano także stosowania manipulacji na zarodkach, których celem miałby być wybór płci dziecka, chyba że taki wybór pozwalałby uniknać poważnej dziedzicznej choroby u dziecka, zależnej od jego płci (Konwencja, art. 14).

Mając na uwadze powyższe wyjaśnienia, należy podkreślić, że Europejska Konwencja Bioetyczna w rzeczywistości nie reguluje kwestii dostępu do in vitro, a jedynie wskazuje, iż w przypadku realizacji tej metody sztucznego zapłodnienia embrionom należy zagwarantować właściwa ochronę. Można, by zadać pytanie: dlaczego Polska konwencji tej nie ratyfikowała, pomimo że apele różnych środowisk, w tym przede wszystkim Helsińskiej Fundacji Praw Człowieka były do poszczególnych rządów w Polsce wielokrotnie kierowane w tym zakresie? Według Jarosława Gowina, ministra sprawiedliwości w rządzie Donalda Tuska, Europejska Konwencja Bioetyczna nie została przyjęta, bowiem „nie było takiej woli politycznej i nie miała jej żadna z ekip rządzących po 1997 r. [...]" (Tumiłowicz 2009: 4). Według ministra, należy dokonać „[...] w pierwszej kolejności ustawowego uregulowania zapłodnienia in vitro, które jest warunkiem przyjęcia konwencji. Komisja bioetyczna zdecydowanie rekomendowała przyjęcie konwencji, przy jednym głosie wstrzymującym się. Najlepiej byłoby, aby konwencja już przez Polskę przyjęta, została ratyfikowana, czyli weszła w życie wraz z ustawa bioetyczna regulująca takie kwestie jak zapłodnienie in vitro" (Tumiłowicz 2009: 4). Próby ustawowego określenia in vitro w Polsce, pomimo kilkakrotnych prób, nie zostały dotychczas zakończone. Podobnie sytuacja wygląda w przypadku ratyfikacji Europejskiej Konwencji Bioetycznej. Zauważalny jest w tym zakresie impas, pomimo iż wola polityczna $\mathrm{w}$ tym zakresie miałaby istnieć, o czym przekonywał w 2012 r. premier Donald Tusk „nie widzimy żadnych przeszkód, aby doszło do jak najszybszej ratyfikacji konwencji bioetycznej” (PAP 2012). 


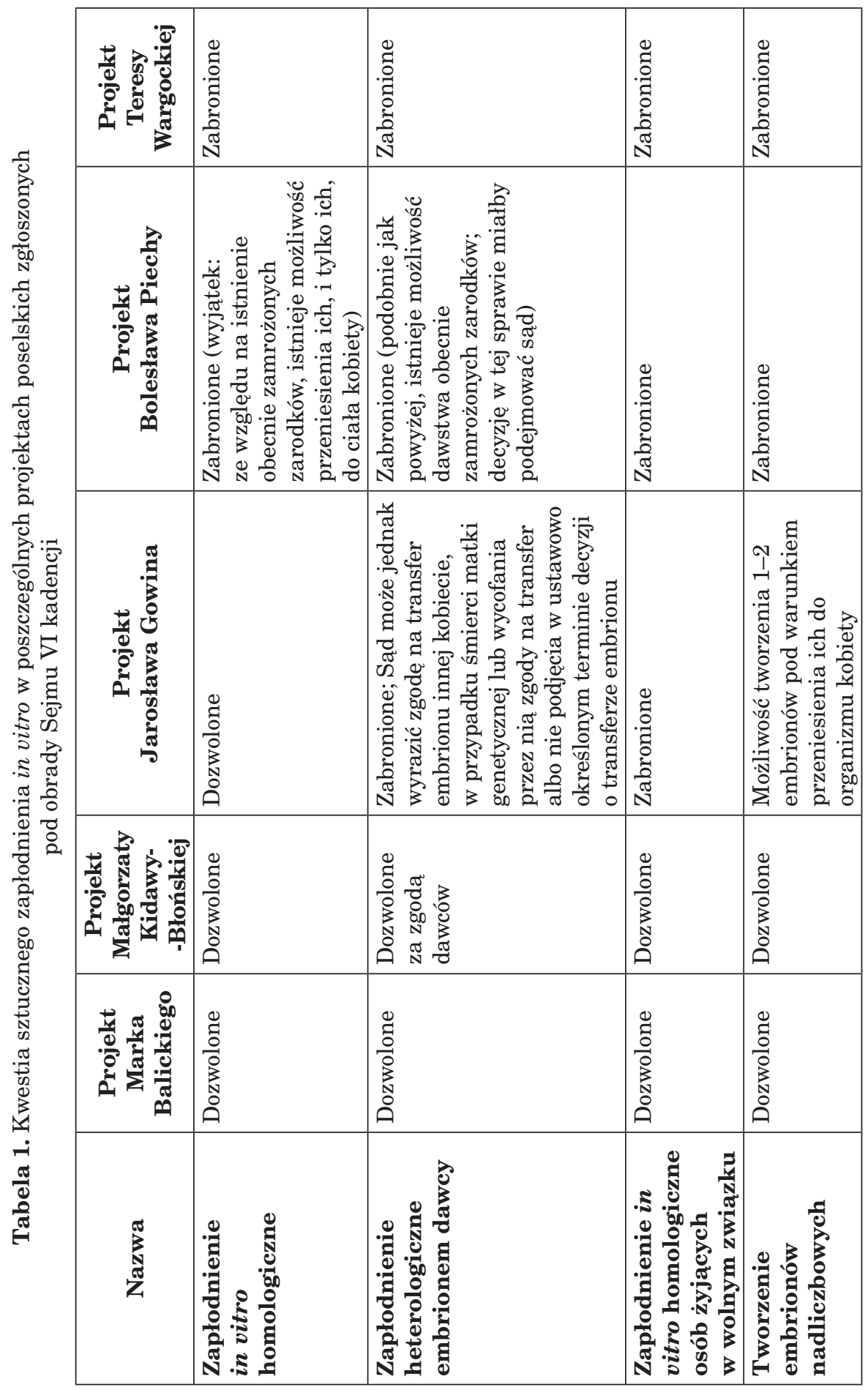


Społeczno-polityczne i religijne aspekty in vitro w Polsce

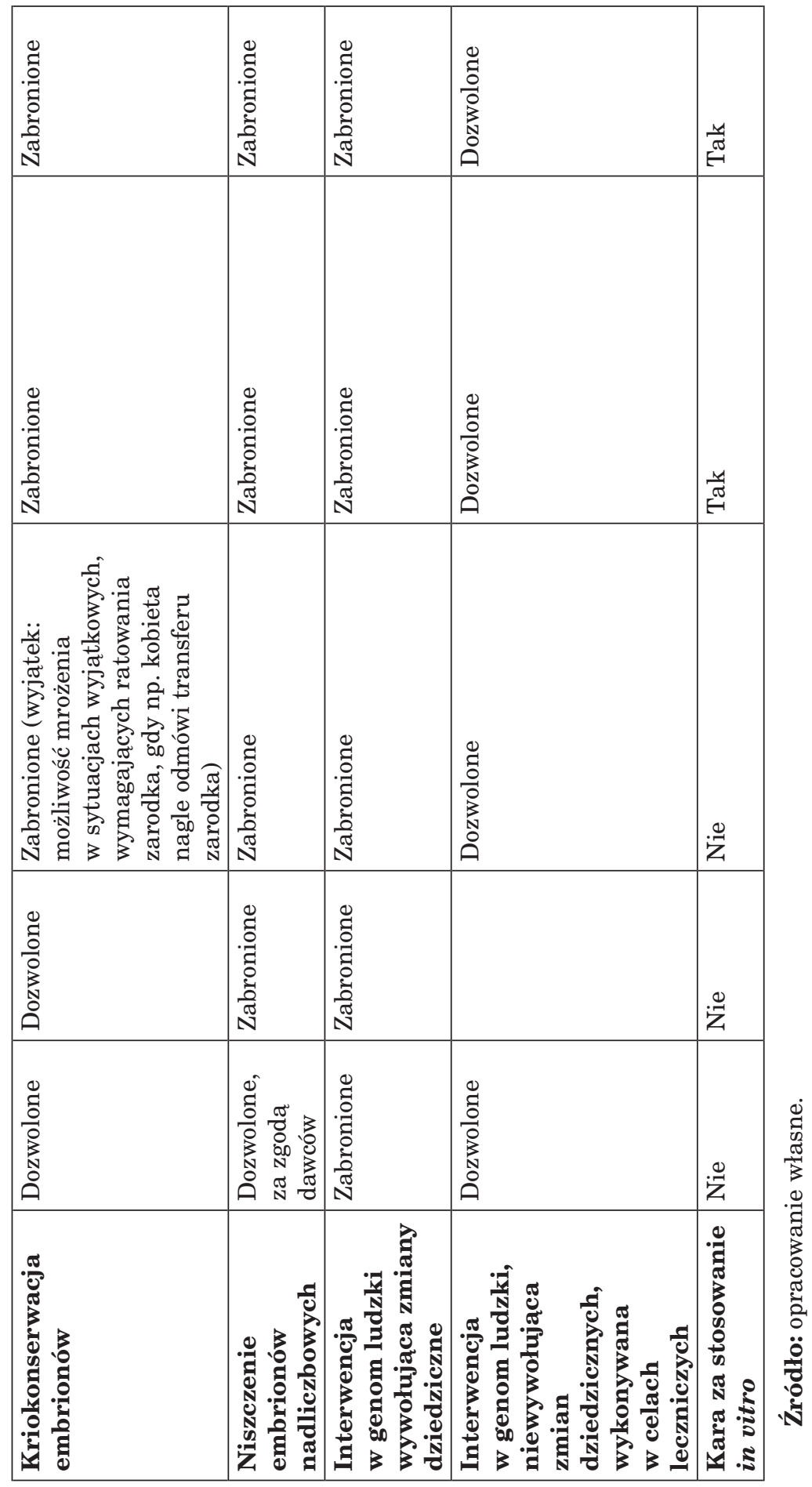


Można przyjąć założenie, że wszystkie mainstreamowe stronnictwa polityczne zgadzaja się, co do konieczności uregulowania kwestii bioetycznych w polskim ustawodawstwie, w tym sztucznego zapłodnienia. Na tym jednak konsensus kończy się, bowiem poszczególne stronnictwa w kwestiach fundamentalnych maja sprzeczne stanowiska. Dyskusja na temat in vitro jest obecna w polskim dyskursie politycznym od wielu lat, jednak dopiero w Sejmie VI kadencji podjęto nieudaną próbę unormowania tej kwestii. Zostało wówczas przygotowanych 5 projektów ustaw. W tabeli 1 wskazano główne założenia poszczególnych projektów. Ułożono je w kolejności od najbardziej liberalnego (projekt Marka Balickiego), zezwalającego na wykonywanie sztucznego zapłodnienia in vitro $\mathrm{u}$ kobiet samotnych, w tym kriokonserwacje i niszczenie nadliczbowych zarodków do skrajnie konserwatywnego podejścia (projekt Teresy Wargockiej), zakazującego stosowania tej metody w przypadku osób niepłodnych, a jednocześnie zakładającego stosowanie kar dla osób stosujących tę metodę. Podczas pierwszego czytania, które odbyło się w październiku 2010 r., wszystkie projekty, poza projektem T. Wargockiej, który został odrzucony, zostały skierowane do dalszych prac w komisjach. Od tego momentu kwestia in vitro znalazła się w pewnej próżni, której nie udało się usunąć w Sejmie VI kadencji. Kolejny Sejm - VII kadencji - kontynuuje prace nad wcześniej wniesionymi projektami. Ponadto, zgłoszony został dodatkowy projekt przez Ruch Palikota, w rzeczywistości oparty na założeniach Marka Balickiego.

Szanse na zakończenie uregulowania kwestii rozrodu wspomaganego w Polsce w okresie VII kadencji Sejmu sa coraz mniej prawdopodobne, pomimo iż Unia Europejska w styczniu 2013 r. wystosowała ultimatum do polskich władz, nakazując podjęcie niezbędnych działań $\mathrm{w}$ celu zapewnienia zgodności prawa krajowego z prawem unijnym, odnośnie do kwestii pobierania i przechowywania ludzkich narządów, tkanek i komórek. Zagadnienia te miały być de facto uregulowane do 2006 r. W przypadku braku rekcji polskich władz w tym zakresie, Unia Europejska zamierza wystapić do Europejskiego Trybunału Sprawiedliwości (Siedlecka 2013b:5). Obecnie droga legislacyjna w zakresie szeroko rozumianych kwestii bioetycznych, w tym sztucznego zapłodnienia została w rzeczywistości zamrożona, bowiem, w kwietniu $2012 \mathrm{r}$. sejmowa komisja ustawodawcza poparła wniosek konserwatywnego posła PO Jacka Żalka, by sprawdzić, czy poszczególne projekty ustaw sa zgodne z art. 38 konstytucji - tym, który gwarantuje ochronę życia (Siedlecka 2013a:8). Sprawę będzie rozstrzygał Trybunał Konstytucyjny, co znacząco wydłuży zakończenie procesu prac legislacyjnych nad ustawami bioetycznymi. 


\section{Opinie i postawy społeczeństwa polskiego na temat sztucznego zapłodnienia}

Problem z naturalnym zapłodnieniem dotyczy coraz większej liczby osób. Szacuje się, że w krajach rozwiniętych niepłodność dotyka ok. 20-25\% par, natomiast w Polsce ten problem dotyczyć może ok. 15-20\% związków. Jednocześnie Światowa Organizacja Zdrowia (WHO) uznała niepłodność za chorobę społeczna (Tykwińska-Rutkowska 2007: 82)

Polska, jak wskazano powyżej, jest jednym z nielicznych państw, gdzie kwestia sztucznego zapłodnienia in vitro wciąż nie jest prawnie usankcjonowana, a jednocześnie istnieje silny opór polityczny, aby kwestię tę uregulować. Istniejący impas w kwestii sztucznego zapłodnienia pomiędzy najważniejszymi ugrupowaniami politycznymi może jednak zaskakiwać, jeśli dokona się analizy badań opinii społecznych prowadzonych w Polsce od 1995 r. przez Ośrodek Badania Opinii Społecznej (OBOP). Od 1995 r. akceptacja dla stosowania tej metody zapłodnienia jest bardzo duża i z niewielkimi zmianami od połowy lat 90 . XX w. jest na podobnym poziomie. Obecnie 77\% dorosłych Polaków uważa, iż małżeństwa niepłodne powinny mieć możliwość skorzystania z tej techniki. Jednocześnie $60 \%$ społeczeństwa uważa, iż prawo do sztucznego zapłodnienia powinny mieć również osoby żyjące w stałym związku niemałżeńskim (60\%). Poparcie dla zapłodnienia in vitro nie jest już jednak takie duże w przypadku samotnych kobiet, dla których możliwe byłoby jedynie zapłodnienie heterologiczne (48\%).

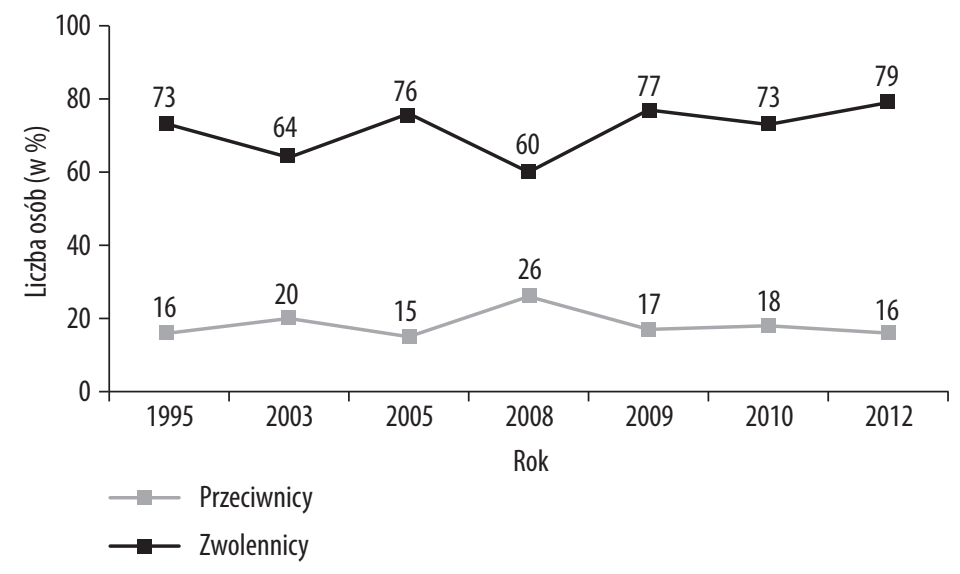

Wykres 1. Opinia Polaków na temat możliwości dokonania zabiegu zapłodnienia in vitro $\mathrm{w}$ przypadku małżeństw mających problem $\mathrm{z}$ zapłodnieniem naturalnym

Źródło: opracowanie własne na podstawie danych CBOS $(2010,2012)$ 


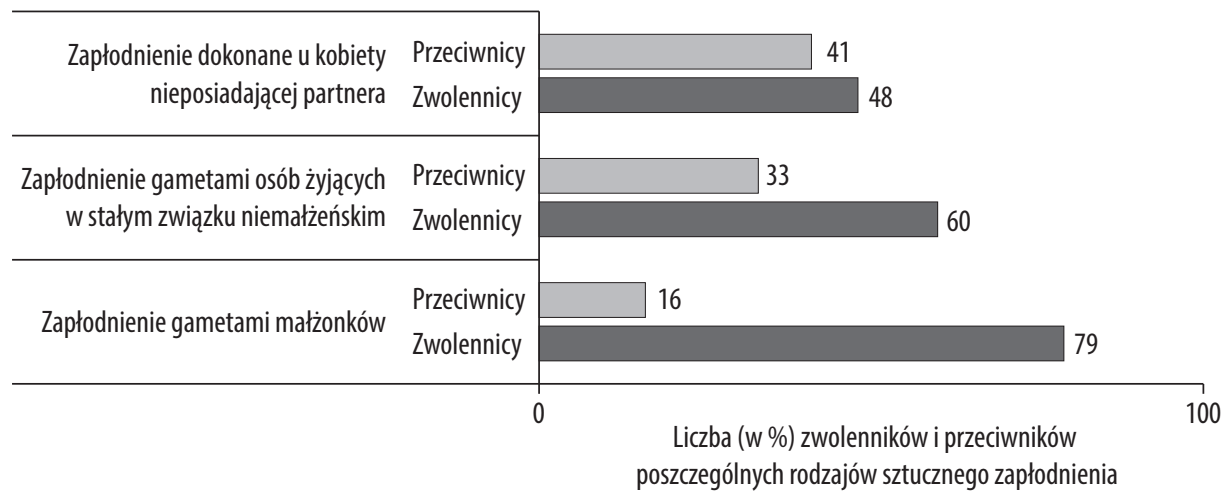

Wykres 2. Opinia Polaków na temat dopuszczalności stosowania poszczególnych form sztucznego zapłodnienia in vitro, na podstawie badań CBOS z $2012 \mathrm{r}$.

Źródło: opracowanie własne na podstawie danych CBOS $(2010,2012)$

Tabela 2. Akceptacja dla sztucznego zapłodnienia a identyfikacja partyjna

\begin{tabular}{|l|c|c|c|}
\hline \multirow{2}{*}{$\begin{array}{c}\text { Potencjalne elektoraty } \\
\text { partyjne }\end{array}$} & \multicolumn{3}{|c|}{$\begin{array}{c}\text { Akceptacja dla sztucznego zapłodnienia } \\
\text { w przypadku małżeństw (w \%) }\end{array}$} \\
\cline { 2 - 4 } & TAK & NIE & $\begin{array}{c}\text { Trudno } \\
\text { powiedzieć }\end{array}$ \\
\hline Ruch Palikota* & 100 & 0 & 0 \\
\hline Platforma Obywatelska & 94 & 4 & 2 \\
\hline Sojusz Lewicy Demokratycznej & 91 & 5 & 4 \\
\hline Polskie Stronnictwo Ludowe & 77 & 21 & 2 \\
\hline Prawo i Sprawiedliwość & 58 & 37 & 5 \\
\hline
\end{tabular}

*Wyniki dotyczące elektoratów RP i PSL należy interpretować ostrożnie, ze względu na niewielką liczbę zwolenników tych ugrupowań w badanej próbie.

Źródło: Raport CBOS (2012), Podstawy wobec stosowania zapłodnienia in vitro.

Silne poparcie w społeczeństwie polskim dla stosowania sztucznego zapłodnienia przez pary będące $\mathrm{w}$ związku małżeńskim jest tym bardziej zaskakujące, gdy dokona się porównania tych wyników z arytmetyka sejmowa. Przez ostatnie dwie dekady politycy żadnego ugrupowania politycznego nie byli w stanie w jakikolwiek sposób uregulować kwestii sztucznego zapłodnienia, zarówno poprzez przyzwolenie na stosowanie tej metody lub jej zakaz. Jednocześnie żadne ugrupowanie w Sejmie w rzeczywistości nie było zainteresowane rozwiązaniem tej kwestii w określony sposób. Można uznać, iż pomimo różnych skrajnych opinii wyrażanych przez polskich polityków na temat sztucznego zapłodnienia, de facto wszystkie stronnictwa polityczne były zainteresowane utrzymaniem status quo w tym zakresie. Środowiska lewicowe, w okresie gdy sprawowały władzę, nie chciały doprowadzać do wojny ideologicznej z hierarchami 
Kościoła katolickiego w Polsce, zwłaszcza że w latach 90. XX w. udało się już wypracować kompromis w jednej ważnej sprawie, jaką była aborcja. Tymczasem w pierwszej dekadzie XXI w. sprawą najistotniejszą była akcesja Polski do UE i poparcie w tym zakresie ze strony Kościoła katolickiego. Jednocześnie środowiska prawicowe, głoszące na ogół konieczność zakazu stosowania in vitro również nie podjęły tego tematu w okresie, gdy władzę sprawowała koalicja Prawa i Sprawiedliwości, Ligi Polskich Rodzin oraz Samoobrony w latach 2006-2007. Można jedynie antycypować, iż być może nie tylko zabrakło czasu, aby ostatecznie zakazać stosowania in vitro, ile być może przeważyło przekonanie, iż lepiej pozostawić tę kwestię nierozwiązana i nie narażać się wyborcom. Niepłodność nie dotyczy bowiem tylko nie-katolików, jak i tylko osób o poglądach lewicowych. Jest to problem nieznajacy barw politycznych. Z badania prowadzonego przez CBOS w $2012 \mathrm{r}$. wynika, iż stosowanie metody in vitro przez małżeństwa jest akceptowane przez zwolenników wszystkich partii, choć najmniejsza aprobata dotyczy elektoratu PiS - 58\% (CBOS 2012).

\section{Dlaczego Polska wciąż nie ma ustawy regulującej kwestie sztucznego zapłodnienia?}

Debata nad uregulowaniem kwestii in vitro w Polsce jest prowadzona przynajmniej od dekady, jednak brak wymaganej w Sejmie zgody uniemożliwia przyjęcie któregokolwiek z projektów. Na podstawie analizy prowadzonego dyskursu należy stwierdzić, iż główną przeszkodą w tym zakresie jest istniejacy konflikt o charakterze religijno-etycznym i ontologicznym. Brak zgody w zakresie jednoznacznego ustalenia statusu ontologicznego zarodka powoduje, że środowiska konserwatywne, na ogół związane z Kościołem katolickim uważaja, że embrion jest początkiem życia i należą mu się tym samym wszelkie prawa, jakie posiada człowiek, a zgoda na in vitro jest de facto zgodą na selektywna aborcję. Tymczasem środowiska skrajnie liberalne sprzeciwiaja się takiemu podejściu, twierdząc jednocześnie, że zarodki mogą być zarówno mrożone, jak i niszczone, bowiem embrion nie jest jeszcze człowiekiem, a jednocześnie zakaz kriokonserwacji spowodowałby podwyższenie kosztów i tak już drogiej procedury sztucznego zapłodnienia.

Należy podkreślić, biorąc pod uwagę fakt, iż religia katolicka odgrywa wciąż ogromną rolę w społeczeństwie polskim, a poszczególne środowiska katolickie, w tym Episkopat Polski ma wpływ na życie polityczne, poszczególne stronnictwa polityczne, w tym rządząca $\mathrm{PO}$, nie sa obecnie zainteresowane ustawowym usankcjonowaniem stosowania in vitro, gdyż oznaczałoby to rozpoczęcie wojny ideologiczno-światopoglądowej, 
a jednocześnie politycznej z Kościołem katolickim. Stanowisko Episkopatu w tym zakresie jest jednoznaczne. Zostało ono przedstawione w liście biskupów do polskich polityków w 2010 r., w którym in vitro nazwano „młodszą siostrą eugeniki” (List biskupów). Jednocześnie abp. Henryk Hoser przed debata prowadzona w Sejmie nad in vitro przestrzegał posłów, że ci, którzy świadomie poprą ustawy dopuszczajace stosowanie metody in vitro automatycznie będą poza wspólnotą Kościoła (Wiśniewska 2010: 4).

$\mathrm{W}$ prowadzonym $\mathrm{w}$ Polsce dyskursie na tematy in vitro ścieraja się różne stanowiska, aczkolwiek najbardziej słyszalnym jest głos przeciwników legalnego usankcjonowania in vitro, co wynika w dużym stopniu $\mathrm{z}$ wykorzystywania silnie emocjonalnie nacechowanego języka. Obecnie można zauważyć, iż środowiska przeciwne stosowaniu metod rozrodu wspomaganego stygmatyzują dzieci poczęte metodą in vitro, nazywając je dziećmi Frankensteina (Harpula 2009) czy twierdząc, tak jak ks. Franciszek Longechamps de Berier, że „[...] są tacy lekarze, którzy po pierwszym spojrzeniu na twarz dziecka wiedza już, że zostało poczęte $\mathrm{z}$ in vitro. Bo ma dotykową bruzde, która jest charakterystyczna dla pewnego zespołu wad genetycznych" (Krzyżak 2013: 83). Przeciwnicy in vitro często wykorzystują w prowadzonym dyskursie „syndrom ocalonego" - używany do opisu zachowań osób, które przeżyły Holocaust (Radkowska-Walkowicz 2012: 32). W takim tonie wypowiedziała się Beata Rusiecka, psychoterapeuta i superwizor grup „Żywa Nadzieja” dla osób z doświadczeniem przemocy, zaniedbania i strat dzieci w Międzynarodowym Stowarzyszeniu Doradców Żywa Nadzieja, według której spotykane są przypadki dzieci, które „,...] posiadaja cechy osób ocalałych od śmierci. [...] Taka osoba przeżywa silne poczucie winy, zadaje sobie pytania: dlaczego ja żyje, czy mam prawo żyć? [...] dzieci poczęte droga in vitro, przez fakt, iż w fazie embrionalnej zostały wybrane przez lekarza spośród innych dzieci, odczuwaja głęboką niepewność dotyczącą swojego prawa do życia” (Jędrzejczyk 2009).

Niechęć rządzących, a przede wszystkim PO, wobec zmierzenia się ze stanowiskiem Kościoła katolickiego w Polsce w zakresie sztucznego zapłodnienia, zwłaszcza że w samej partii istnieje podział pomiędzy skrzydłem konserwatywnym a liberalnym należy uznać zatem za główna przyczynę inercji występującej wśród polityków. Drugim powodem, który można uznać za również bardzo ważny, jest kwestia finansowa. Usankcjonowanie in vitro stanowiłoby w rzeczywistości krok w kierunku żądań do finansowania bardzo kosztownej metody leczenia, która obecnie jest stosowana głównie przez bogatszą część społeczeństwa. Tymczasem, według ministra finansów Jacka Rostowskiego, Polski nie stać w kryzysie na refundacje sztucznego zapłodnienia (Grochal 2012: 5). Dlatego też salomonowym wyjściem z patowej sytuacji może okazać 
się program zdrowotny ${ }^{1}$ zapowiedziany przez rząd, według którego pary, które spełnią określone kryteria ${ }^{2}$, będą miały sfinansowane trzy próby zapłodnienia pozaustrojowego. Program w rzeczywistości stanowi pozorne zwycięstwo rządu, bowiem z jednej strony wycisza na moment głosy tych, którzy uważają, iż PO kapituluje przed opozycją i Kościołem katolickim, a z drugiej strony z programu znacznie łatwiej rządowi będzie wycofać się, w przypadku zaistnienia nieoczekiwanych trudności. Ponadto, finansowaniem ma być objętych jedynie 15 tysięcy par, co stanowi tylko część wszystkich potrzebujących. Nie będzie to zatem stanowiło zagrożenia dla budżetu państwa.

\section{Bibliografia}

Akceptacja stosowania zaptodnienia in vitro, (2009), Komunikat z badań CBOS, Warszawa. Aleksiejuk A. (2008), Kościót prawostawny a problem zaptodnień in vitro, „Życie i Płodność", $\mathrm{nr} 2-3$, s. 54 .

Donum vitae. Instrukcja o szacunku dla rodzacego się życia ludzkiego i o godności jego przekazywania (1987), Kongregacja Nauki Wiary.

Etyczne aspekty zaptodnienia in vitro, (2010), Komunikat z badań CBOS, Warszawa.

Grochal K. (2012), Dlaczego Tusk boi się in vitro?, „Gazeta Wyborcza”, 14.07.2012.

Instrukcja Dignitas personae dotyczaca niektórych problemów bioetycznych (2008), Kongregacja Nauki Wiary.

Jędrzejczyk M. (2009), Dziecko za cenę mitości (rozmowa z Beatą Rusiecką), „Nasz Dziennik", nr 20, 25.01.2009.

Konwencja o ochronie praw cztowieka i godności istoty ludzkiej $w$ dziedzinie zastosowania biologii i medycyny (1997), Rada Europy.

Makosz J. (2008a), Zaptodnienie in vitro w świetle żydowskiego prawa religijnego, „Życie i Płodność", nr 2-3.

PAP (2012), Tusk: ratyfikacja konwencji bioetycznej nie zmieni prawa aborcyjnego, „Gazeta Wyborcza", 3.03.2012.

Postawy wobec stosowania zaptodnienia in vitro (2012), Komunikat z badań CBOS, Warszawa.

Radkowska-Walkowicz M., (2012), The creation of „monsters”: the discourse of opposition to in vitro fertilization in Poland, „Reproductive Health Matters”, vol. 20.

\footnotetext{
${ }^{1}$ Przyjęcie programu zdrowotnego oznacza ominięcie drogi ustawowej. Według opozycji takie rozwiąanie problemu jest prawnie wątpliwe, co może oznaczać skierowanie tej sprawy do Trybunału Konstytucyjnego w celu zbadania konstytucyjności tego rozwiązania.

${ }^{2} \mathrm{Z}$ programu finansowania in vitro, obowiąujacego od 1.07.2013 r., moga skorzystać pary (kobieta nie może mieć ukończonych 40 lat), które wcześniej nie miały wykonywanych prób in vitro i u których stwierdzono bezwzględną przyczynę niepłodności lub nieskuteczne leczenie niepłodności w ciagu ostatniego roku przed zgłoszeniem się do programu. Ośrodki będą miały obowiązek przechowywania niewykorzystanych zarodków. Kolejny cykl pobrania i zapłodnienia komórki jajowej nie będzie mógł być wykonany bez wykorzystania wcześniej uzyskanych i przechowywanych zarodków. Maksymalnie finansowane będą 3 próby zapłodnienia in vitro u danej pary.
} 
Siedlecka E. (2013a), No i Platforma zamrozita in vitro, „Gazeta Wyborcza”, 27.04.2013. Siedlecka E. (2013b), Komisja Europejska grozi Polsce za in vitro na dziko, „Gazeta Wyborcza", 28.01.2013.

Szewczyk K. (2009), Bioetyka. Medycyna na granicach życia, t. 1, Wydawnictwo Naukowe PWN, Warszawa.

Tumiłowicz B. (2009), Dlaczego Polska nie chce ratyfikować Konwencji Bioetycznej Rady Europy?, „Przeglą”, nr 2.

Tykwińska-Rutkowska D. (2007), Zaptodnienie in vitro - problematyka administracyjnoprawna (na kanwie orzeczenia WSA z dnia 2006-08-30), „Prawo i Medycyna”, vol. 9 , $\mathrm{nr} 3$.

Zagrodzki W. (2008), Dlaczego „nie” zapłodnieniu in vitro? Życia nie można „produkować” (wywiad z o. prof. Wojciechem Bołozem), „Homo Dei”, nr 4.

\section{Netografia}

Ali A., (bdw.), The Conditional Permissibility of In Vitro Fertilisation Under Islamic Jurisprudence [w:] http://alghazzali.org/resources/ivf.pdf. (dostęp: 20.03.2013).

Grzymkowska M. (bdw.), Konwencja o Prawach Człowieka i Biomedycynie, [w:] www. hfhrpol.waw.pl/precedens/images/stories/konwencja_overview.pdf(dostęp:20.03.2013).

Harpula W. (2009), „Pierwowzorem in vitro jest Frankenstein” (rozmowa z bp. T. Pieronkiem w onet.pl), [w:] http://wiadomosci.onet.pl/wiadomosci/pierwowzorem-in-vitro-jest frankenstein,1,3492964,wiadomosc.html (dostęp: 20.03.2013).

Krzyżak T. (2013), In vitro niczego nie załatwia, „Uważam Rze. Inaczej Pisane”, nr 9.

List biskupów do polityków: „In vitro to młodsza siostra eugeniki”, (2010), [w:] http:// jadwigalegnica.pl/a/episkopat-polski/68-rone/695-list-biskupow-do-politykow-qin-vitro-to-modsza-siostra-eugenikiq (dostęp: 20.03.2013).

Makosz J. (2008b), Życie i płodność wedtug judaizmu, „Życie i Płodność”, nr 1.

Oświadczenie Kościoła Ewangelicko-Augsburskiego w RP w sprawie dopuszczalności stosowania metody in vitro (2009), [w:] www.old.luteranie.pl (dostęp: 20.03.2013).

Wiśniewska K. (2010), Ekskomunika za in vitro, „Gazeta Wyborcza”, z dn. 18.10.

www.wyborcza.pl/1,76842,11277036,Tusk_ratyfikacja_konwencji_bioetycznej_nie_ zmieni.html\#ixzz2Mhg369Ia (dostęp: 20.03.2013).

\section{The socio-political and religious aspects of „in vitro” in Poland}

In vitro fertilization (IVF) is one of the main medical problems invoking extreme opinions and dividing different social groups. In Poland, even though private infertility clinics use in vitro to help infertile people, using this method is still not regulated by Polish law. This article presents the aspect of in vitro in Poland and also the issue concerning the difficulties in finding a consensus between different social, religious and political groups as far as the acceptance of specific law regulations is concerned. In the article different views are presented - in the first place the opinion of chosen religions and political parties - as far as the acceptability of using in vitro by infertile people is concerned. Moreover, the author indicates the chosen examples of the leading discourse about in vitro in Poland. The article presents different ways of stigmatizing both people who are using in vitro and people born after the application of this method.

Key words: in vitro fertilization, embryo, discourse, legislative projects, religion, politics. 